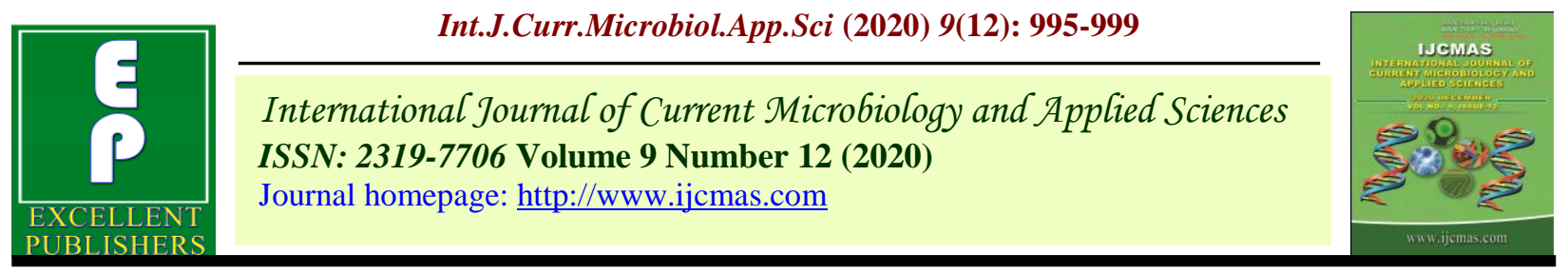

Original Research Article

https://doi.org/10.20546/ijcmas.2020.912.120

\title{
Evaluation of Suitable Culture Media for Growth of Rhizoctonia bataticola Causing Dry Root Rot of Chickpea (Cicer arietinum)
}

\author{
Anurag Shukla ${ }^{1 *}$, Ved Ratan ${ }^{1}$, R K Mishra ${ }^{2}$, U.K. Tripathi ${ }^{1}$, Krishna Kumar ${ }^{2}$, \\ D. R. Singh ${ }^{3}$, R.K. Pathak ${ }^{4}$, Javed Bahar ${ }^{1}$ and Anjani Kumar Singh ${ }^{5}$
}

${ }^{1}$ Department of Plant Pathology, ${ }^{3}$ Department of Entomology, ${ }^{4}$ Department of Soil Science \& Agri. Chemistry, ${ }^{5}$ Department of Agri. Economics \& Statistics, C.S.A.U.A \&T, Kanpur-2, Uttar Pradesh, India

${ }^{2}$ Division of Crop Protection, IIPR, Kanpur-2, Uttar Pradesh, India

*Corresponding author

\section{A B S T R A C T}

\section{Keywords}

\section{Rhizoctonia}

bataticola, Cultural growth, Dry weight, Broth,

Macrophomina phaseolina

\section{Article Info}

Accepted:

10 November 2020

Available Online:

10 December 2020
Rhizoctonia bataticola (Taub.) Butler is the causal organism of dry root rot of chickpea. Its Pycnidial stage is found in Macrophomina phaseolina (Tassi) Goid. It is soil inhabiting fungal pathogen. Keeping in view the consequentiality of the disease due to transmute in climatic conditions, studies were conducted on distribution of the disease, cultural, morphological, pathological and molecular diversity. This research was conducted at Department of Plant Pathology, CSAUA \& T, Kanpur, in collaboration with Indian Institute of Pulses Research, Kanpur. In this research, dry root rot affected samples were collected from different farms of Uttar Pradesh. A total of fifty R. bataticola isolates of were isolated from these samples. Eight different culture media were used in this study for evaluation of the best for growth of Rhizoctonia bataticola. The fungus $R$. bataticola gives maximum cultural growth on potato dextrose agar $(88.63 \mathrm{~mm})$ followed by corn meal agar $78.36 \mathrm{~mm}$ and oat meal agar $73.36 \mathrm{~mm}$ while potato dextrose rose bengal agar showed least growth of $28.50 \mathrm{~mm}$ in solid media. Among the eight liquid broth media tested, potato dextrose broth revealed the highest mean mycelial dry weight $(158.50 \mathrm{mg})$ followed by corn meal broth $(130.90 \mathrm{mg})$, oat meal broth $(127.60 \mathrm{mg}), \mathrm{V}-8$ juice broth $(119.10 \mathrm{mg})$ while potato dextrose rose bengal broth gives the least mycelial dry weight $(53.60 \mathrm{mg})$. Production of sclerotia was maximum in PDA and least in SDA.

\section{Introduction}

Chickpea (Cicer arietinum L.) is a leguminous crop commonly known as "Chana or Bengal Gram”. Chickpea belongs to family Leguminaceae, cultivated in many countries. It is rich in nutritional values in the diet of vegetarian Indian people as it contains 21.1 per cent protein, 61.5 per cent carbohydrates and 4.5 per cent fat, 6 per cent crude fiber and 6 per cent soluble sugar (Ahlawat et al., 1996). The causal organism of dry root rot of chickpea is Rhizoctonia bataticola. It is a soil inhabiting fungi. It is a necrotrophic fungal pathogen which is seed and soil borne in nature (Sharma and Pande, 2013). It is one of 
the important diseases which mostly occurs under drought conditions and prevail at seedling, flowering and podding stage of the crop. It is widely distributed and infects both monocot and dicot plants, ranging more than 284 plant species (Farr et al., 1995).

The growth of $R$. bataticola is enhanced by high soil temperature i.e. more than $30^{\circ} \mathrm{C}$ ) and low soil moisture condition which favours its growth. The existence of DRR was first described by Padwick in chickpea with wilt (Padwick, 1948). Significant reduction of 2570 per cent in chickpea production due to this disease in India has been reported (Ahmed and Ahmed, 1969; Pande and Sharma, 2010). Viability and growth of Rhizoctonia bataticola is also affected by environmental conditions like increase in temperature due to global warming, low soil moisture due to low rainfall and high soil $\mathrm{pH}$ i.e. alkalinity of soil (Khare et al., 1970).

\section{Materials and Methods}

\section{Collection, isolation and purification of the pathogen}

For collection of dry root rot affected plant survey was done to record the disease incidence and spreading of dry root rot of chickpea in 75 different places in Uttar Pradesh, India. Major chickpea growing districts in Uttar Pradesh viz. Kanpur Nagar, Kanpur Dehat, Jhansi, Mahoba, Fatehpur, Unnao and Ayodhya during Rabi 2019.

Chickpea roots showing typical symptoms of dry root rot symptoms were taken for isolation. These roots were washed under tap water to remove the soil and other dirt. 4-5 $\mathrm{mm}$ bits or pieces of root were taken for isolation. During isolation these bits were surface sterilized by 1 per cent sodium hypochlorite $(\mathrm{NaOCl})$ solution followed by washing twice in sterile distilled water, dry these bits by placing it on sterile blotter paper now these bits were transferred on sterilized PDA media which was poured previously, by using forceps and placed in BOD incubator for incubation at $28 \pm 2^{0} \mathrm{C}$ (Anurag and Ved, 2019). The fungal colonies emanating from bits were examined on 4 days of incubation growing mycelium was marked on the underside and viewed through a light microscope.

\section{Growth of Rhizoctonia bataticola isolates on solid \& liquid media}

The growth of R.bataticola on different type of solid media viz., corn meal agar, rose bengal agar, pikovskaya agar, sabouraud dextrose agar, potato dextrose rose bengal agar, V-8 juice agar, oat meal agar and potato dextrose agar media were compared by using liquid and solid media separately. $100 \mathrm{ml}$ of liquid media i.e. media without agar, was prepared in $250 \mathrm{ml}$ conical flask, a pinch of streptomycin was added as antibiotic in each flask. For solid media, $100 \mathrm{ml}$ of each media was prepared and 15 to $20 \mathrm{ml}$ of each media was transferred to petri plates just before pouring a pinch of streptomycin was added as antibiotic in each flask. Fungal inoculum was added to conical flask by transferring a little bit of mycelial mat by using cork borer, taken from seven days culture. The plates were incubated at $28 \pm 2^{0} \mathrm{C}$ for two days and replicated thrice. Potato dextrose agar plates were used as control. The radial mycelial growth was measured five days after incubation.

For the inoculation of $R$. bataticola on conical flask mycelial disc $(5 \mathrm{~mm})$ was taken from 5 days old culture and inoculated separately into each $250 \mathrm{ml}$ conical flask having sterilized corn meal broth, rose bengal broth, pikovskaya broth, sabouraud dextrose agar, potato dextrose rose bengal broth, V-8 juice, oat meal agar and potato dextrose broth and 
was kept inside BOD incubator for incubation at temperature $\left(28 \pm 2^{\circ} \mathrm{C}\right)$ for ten days. After ten days the mycelial mat was separated from remaining broth by using Whatman No.1 filter paper and sun dried for 4 days and weighed immediately on an electronic balance (Sharma and Pande, 2013). The conical flask containing potato dextrose broth was used as control. The dry weight of mycelium from each broth was recorded.

\section{Results and Discussion}

Radial growth and Mycelial dry weight of R.bataticola isolates on different solid and liquid media. There was significant difference in radial growth among different mediums. The mean radial mycelial growth of the isolates on different solid media was studied and it was ranged between $28.50 \mathrm{~mm}$ and $88.63 \mathrm{~mm}$. Among the eight solid media, potato dextrose agar medium was significantly superior and recorded the highest mycelial growth of $88.63 \mathrm{~mm}$ and this was followed by corn meal agar $(79.46 \mathrm{~mm})$, oat meal agar (73.36 mm), V-8 juice agar (68.68 $\mathrm{mm})$, rose bengal agar $(62.50 \mathrm{~mm})$, pikovskaya agar $(55.30 \mathrm{~mm})$ and sabouraud dextrose agar $(46.66 \mathrm{~mm})$ and potato dextrose rose bengal agar media $(28.50 \mathrm{~mm})$ (Table 1 and Plate 1).

In conclusion, maximum growth in PDA may be due to presence of some additional nutrients in this media (Devi and Singh, 1998). A similar finding on effect of different media on growth of $R$. bataticola was given by (Sundravadana et al., 2012). The same trend was observed in liquid medium, mycelial dry weight of $R$. bataticola was maximum in potato dextrose broth and was significantly superior in all the eight media tested, the lowest mycelial dry weight 53.66 $\mathrm{mg}$ was given by potato dextrose rose bengal broth. (Suriachandra et al., 2003) studied on growth different media and reported $R$. bataticola grew best on PDA, corn meal agar and oat meal agar. Sclerotial production was excellent on PDA.

Table.1 Growth of $R$. bataticola culture on different liquid and solidified media

\begin{tabular}{|c|c|c|c|c|c|}
\hline S.No. & Media & $\begin{array}{l}\text { Mycelial growth } \\
\text { in } \mathbf{m m} \\
\text { (Mean of three } \\
\text { replication) }\end{array}$ & $\begin{array}{l}\text { Mycelial dry } \\
\text { weight (mg) } \\
\text { (Mean of three } \\
\text { replication) }\end{array}$ & Sporulation & Colony Colour \\
\hline 1 & Corn meal agar & 79.46 & 130.90 & ++++ & Dark Greyish Black \\
\hline 2 & Oat meal agar & 73.36 & 127.60 & +++ & Greyish Black \\
\hline 3 & Pikovskaya agar & 55.30 & 94.60 & ++ & Grey \\
\hline 4 & Potato dextrose agar & 88.63 & 53.66 & ++++ & Dark Black \\
\hline 5 & $\begin{array}{l}\text { Potato dextrose rose } \\
\text { bengal agar }\end{array}$ & 28.50 & 158.50 & + & Whitish Grey \\
\hline 6 & Rose bengal agar & 62.50 & 102.10 & +++ & Dark Gray \\
\hline 7 & Sabouraud dextrose agar & 46.66 & 88.50 & + & Grey \\
\hline 8 & V-8 Juice agar & 68.68 & 119.10 & +++ & Dark Gray \\
\hline \multicolumn{2}{|r|}{ SEm \pm} & 0.55 & 0.75 & & \\
\hline \multicolumn{2}{|r|}{ CD at $5 \%$} & 1.60 & 1.70 & & \\
\hline
\end{tabular}

++++ High Sporulation

$+++\&++$ Medium Sporulation

+ Low Sporulation 
Plate.1 Different culture of $R$. bataticola on eight different solid media

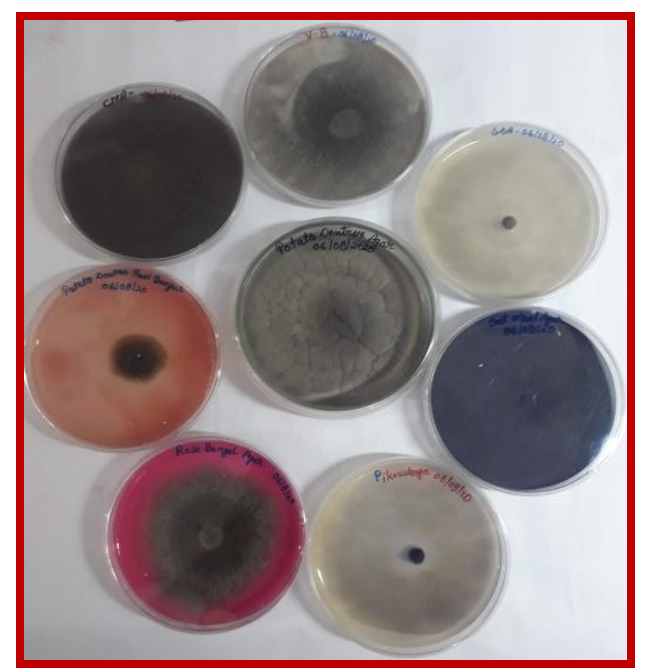

There was a significant difference in mycelial dry weight growth between different incubation periods (Table 1). Dry mycelial weight was found to be maximum on 15th day of incubation period $(158.50 \mathrm{mg})$ and remained significantly superior over other seven treatments. Dry mycelial weight increased up to 15 days followed by the subsequent reduction in weight. The reduction in weight of mycelium is due to autolysis of the mycelium and due to lack of nutrients in the medium when incubated after optimum number of days. The present studies confirmed the variability in mycelial growth and mycelial dry weight of $R$. bataticola cultured in various culture media.

Colony colour and sporulation of $R$. bataticola were studied on different agar media (Table 1). Maximum sporulation i.e. production of sclerotia was on potato dextrose agar and corn meal agar media followed by oat meal agar, V-8 juice agar and rose bengal agar. Least sporulation was given by sabouraud dextrose agar and potato dextrose rose bengal agar. Colony colour was also different with different media with PDA media its culture gives dark black colour likewise with corn meal agar media it gives dark greyish black and with potato dextrose rose bengal agar it gives whitish grey colour (Aboshosha et al., 2007; Fernandez et al., 2006).

\section{Funding}

The funding was given by Chandra Shekhar Azad University of Agriculture \& Technology, Kanpur, Uttar Pradesh, India in collaboration with Indian Institute of Pulses Research, Kanpur, Uttar Pradesh, India

\section{Conflicts of interest}

On behalf of all authors, the corresponding author states that there is no conflict of interest.

\section{Ethics approval}

This article does not contain any studies with human participants or animals performed by any of the authors.

\section{Consent for publication}

On behalf of all authors, the corresponding author states that consent is given for publication.

\section{Acknowledgement}

This research was supported by Department of Plant Pathology Chandra Shekhar Azad University of Agriculture \& Technology, Kanpur in collaboration with Indian Institute of Pulses Research, Kanpur. 


\section{References}

Aboshosha, S.S., Atta Alla, S.I., El-Korany, A.E and El-Argawy, E. 2007. Characterization of Macrophomina phaseolina isolates affecting sunflower growth. Int. J. of Agric. and Biol. 9(6): 807-815.

Ahlawat, I.P.S.; Omprakash; Singh, P.K. (1996). Nutritional value of chickpea grains. In: Principles of Agronomy and Crops. Rama Publishing House, Meerut, India pp. 43.

Ahmed, N., and Q.A. Ahmed. (1969). Physiologic specialization in Macrophomina phaseoli (Maubl.) Ashby, causing stem rot of Jute, Corchorus species. Mycyopath. Mycol.Appl. 39: 129-138.

Anurag Shukla and Ved Ratan. (2019). Management of Early Blight of Potato by Using Different Bio-agents as tuber dressing and its effect on germination and growth.. Int.J.Curr.Microbiol. App.Sci. 8(6): $\quad$ 1965-1970. doi: http://doi.org/10.20546/ijcmas.2019.806.2 33

Devi, T. P and Singh, R. H., (1998). Cultural variation of Macrophomina phaseolina isolates collected from Vigna mungo. Indian Phytopathol., 51(3): 292- 293.

Farr DF, Bills GF, Chamuris GP, Rossman AY (1995). Fungi on Plants and Plant Products in the United States, 2nd ed. St Paul, MN: APS Press.

Fernandez, R.B., Santiago, A.S., Delgado, S.H and Mayek-Perez, N. 2006. Characterization of Mexican and NonMexican isolates of Macrophomina phaseolina based on morphological characteristics, pathogenicity on bean seeds and endoglucanase genes. J. of
Plant Pathol. 88 (1): 53-60.

Khare, M. N., Jain, N. K. and Sharma, H. C., (1970). Variation among Rhizoctonia bataticola isolates from urdbean plant parts and soil. Phytopathol., 60: 1298.

Padwick, G.W. (1948). Plant protection and food crops of India, plant pest and disease at rice, wheat, sorghum and gram. Imp. J. Exp. Agri. 16: 55-64.

Pande, S. and Sharma, M. (2010). Climate Change: Potential Impact on Chickpea and Pigeonpea Diseases in the Rainfed Semi-Arid Tropics (SAT). In: 5th International Food Legumes Research Conference (IFLRC V) \& 7th European Conference on Grain Legumes (AEP VII) April 26-30, 2010. Antalya, Turkey.

Sharma M and Pande S. (2013). Unravelling effects of temperature and soil moisture stress response on development of dry root rot [Rhizoctonia bataticola (Taub.)] butler in chickpea. Am. J. of Plant Sci. 4:584-589.

Singh, R.D.N. and Kaiser, S.K.M. (1995). Evaluation of some elite genotypes of maize for resistance to charcoal rot disease. J. Mycopathol. Res., 29: 141147.

Sundravadana, S, Alice, D and Thirumurugan, S. (2012). Exploration of variability in colony morphology and virulence of Rhizoctonia bataticola isolates causing dry root rot of pulses. Glob. J. Bioscience and Biotechnology., 1(1): 2278 9103.

Suriachandra Selvan M, Seetharaman K. (2003). Effect of culture media on growth and sclerotial production of different isolates of Macrophomina phaseolina infecting sunflower. J. of Mycol. and Plant Pathol. 2003; 33:226-229.

\section{How to cite this article:}

Anurag Shukla, Ved Ratan, R K Mishra, U.K. Tripathi, Krishna Kumar, D. R. Singh, R. K. Pathak, Javed Bahar and Anjani Kumar Singh. 2020. Evaluation of Suitable Culture Media for Growth of Rhizoctonia bataticola Causing Dry Root Rot of Chickpea (Cicer arietinum). Int.J.Curr.Microbiol.App.Sci. 9(12): 995-999. doi: https://doi.org/10.20546/ijcmas.2020.912.120 